\title{
Determinants of yield differences in small-scale food crop farming systems in Cameroon
}

\author{
Genesis T Yengoh
}

\begin{abstract}
Background: In sub-Saharan Africa, small-scale farmers make up the majority of food producers. While recognizing that the yields per hectare for main food crops are generally low in small-scale food production systems in this region, there are considerable differences in yield output among individual farmers. At the very local scale, why do these differences exist? By examining factors that are associated with yield differences, policy can be better informed and tailored to respond to challenges of food production among this important group of producers.

Results: When the influence of biophysical factors is controlled by sampling farmers within the same environment, the analysis distinguishes three clusters of factors with which food crop yield differences can be associated: the input, management and socio-cultural clusters. In the input cluster, the use of basic inputs such as animal droppings and improved seeds do significantly improve yields. However, there are constraints at farm and household levels that may have to be overcome to optimize the availability and use of these inputs. In the farm management cluster, the method of residue management and the control of pests and crop diseases are important in determining yield differences. Issues of gender rights and access to agricultural production resources dominate socio-cultural clusters.

Conclusions: Small investments that are properly targeted to improve basic techniques of farming can make an appreciable difference in food crop yields and food security at the local level. While directed investments in services such as extension may contribute significantly to propagate the use of some technologies (composting, residue management, manure use), cost constraints limit the propagation of other technologies (advanced seed development and improvement, production of inorganic fertilizers) to higher levels of food governance systems. Women form an important population among small-scale farmers and play an indispensable role in food production. Addressing constraints to their access to food production resources (physical, financial, cultural, legal) would be a vital step towards sustainably improving food production. Present food demand trends in sub-Saharan Africa offer an opportunity through which many small-holder farming communities can be drawn out of poverty if some local-level challenges to yield improvement can be overcome.
\end{abstract}

Keywords: Food crops, Yields, Yield-gap, Farm management, Small-scale farming, Food security, Food security, Cameroon, Sub-Saharan Africa

\section{Background}

The global demand for food is expected to rise steeply as a result of burgeoning population, shifting dietary preferences and increasing demands for renewable energy. In 2009 the Food and Agriculture Organization of the United Nations estimated that global food production must increase by $70 \%$ to meet demands in 2050 [1]. At the same time, climate change, water scarcity and land-use change are

Correspondence: yengoh.genesis@lucsus.lu.se

Department of Physical Geography and Ecosystem Sciences, Geobiosphere Science Centre, Lund University, Sölvegatan 12, Lund SE-223 62, Sweden expected to jeopardize continued increases in agricultural production [1,2], thus making food security an emergency that calls for a variety of policies and creative solutions at global, regional and local levels [3]. The most important prospects for increased food production in the near future are seen in areas where the current land productivity is significantly lower than the potential [4]. These differences between actual and potential production are believed to be especially wide in sub-Saharan agricultural systems where large portions of the land are still under subsistence farming. This calls into question the efficiency of the food

\section{Biomed Central}


production process among small-scale farmers who form the bulk of food crop producers in this part of the world.

The farm, managed by individuals, households and common initiative groups, is the most basic unit of analysis for the food production system, agricultural transformation and their associated problems. Natural factors in terms of soils, water and climate are decisive for creating, enabling or constraining bio-physical conditions for food production [5]. Land and labor, on the other hand, are the main social factors to be harnessed through organization in terms of time management, division of labor, cooperation and the deployment of technology such as seeds, livestock, nutrients and equipment [6,7]. These are local factors with which farmers have to deal continuously as they engage in food crop production. The local scale of food crop yield characterization and analysis is therefore important. This is especially true for developing countries where agricultural development still depends heavily on direct farmer-to-farmer interactions either as individuals or within the framework of their common initiative groups. Agricultural extension workers and other agents of agricultural development and change still undertake closer face-to-face interaction with farmers in developing countries than in countries with mature agricultural production systems. The management of natural and human resources of agricultural production at the very local level determines the success or failure in closing the yield gap. This is the case of the world's semi-arid and dry sub-humid savannah and steppe regions, where the large yield-gaps are not a result of limited water to support the predominantly rain-fed agriculture per se, but rather are the result of inefficient management of available water, soil and crops [8]. Multiple stressors contributing to food insecurity have been identified at the global level [9]. Analysis at the local level can unravel the multiple interacting constraints to food crop production and factors that drive or sustain the yield-gap.

This study asks the question of whether associations can be drawn between farmer management practices as well as the sociocultural characteristics of farming households and food crop yields. Using data derived from participatory research, site studies and surveys, the article presents the relationship between key biotic and abiotic factors of small-scale farming systems and food crop yields. In each case, attempts and challenges associated with optimizing food crop yields are discussed at scales ranging from the small-scale farmers' level to the level of national agricultural policy. An understanding of such associations at the local level is important in guiding agricultural development policy, the allocation of resources, land-use planning, and planning for attaining present and future food security needs of the community in question.
The context of food production in the Western Highlands of Cameroon

Boyo is an administrative division in the North West region of Cameroon. The North West and West administrative zones are situated in the Western Highlands agroecological zone. The Western Highlands of Cameroon is one of the five main agro-ecological zones of the country. The area lies between latitudes $4^{\circ} 54^{\prime} \mathrm{N}$ and $6^{\circ} 36^{\prime} \mathrm{N}$, and between longitudes $9^{\circ} 18^{\prime} \mathrm{E}$ and $11^{\circ} 24^{\prime} \mathrm{E}$. In 2006 the population of Boyo Division was about 170,000 on a surface area of $1,592 \mathrm{~km}^{2}$.

\section{Biophysical context}

The climate of the Western Highlands agro-ecological zone is of the tropical humid mountain type. This climate has two seasons: the rainy season that lasts from about mid-March to October, and the dry season from November to about mid-March [10]. The annual rainfall varies from approximately $1,300 \mathrm{~mm}$ in the plains to over 3,000 $\mathrm{mm}$ on highland peaks. Most of the agricultural activity takes place during the rainy season since the region is very poorly equipped with irrigation infrastructure, with less than 3\% capacity concentrated around the Ndop Plain where favorable topography and the availability of a dam combine to provide conducive conditions. Mean monthly temperatures range from about $15^{\circ} \mathrm{C}$ on the highlands to about $27^{\circ} \mathrm{C}$ in low-lying regions.

The terrain of the Western Highlands agro-ecological zone consists mainly of plateaus and areas of depression ranging from 1,000 to $2,300 \mathrm{~m}$ above sea level (Figure 1). Weathered red, tropical, ferralitic soils dominated by lowactivity kaolinite clays and high quantities of sesquioxides are the common agricultural soils of the region [11]. These clayey soils have a deep solum (several meters thick), a reddish hematite subsurface, a weak macrostructure and high friability, especially when dry [11]. Micro-aggregates in the soil reduce moisture storage at field capacity, thereby limiting its available water capacity [11]. The agronomic implications of this low capacity to hold available water is that the soil is poorly equipped to supply crops with much-needed moisture during periods of drought and long dry spells that are increasingly common in the Western Highlands agro-ecological zone.

When low-input sedentary subsistence farming replaces the natural vegetation over ferrasols, the stable natural biogeochemical processes of nutrient cycling are disrupted and the root zone (the upper 10 to $50 \mathrm{~cm}$ ) becomes rapidly depleted of plant nutrients [11]. Soil fertility can be maintained by a combination of the application of manure, composting, mulching, liming and the use of inorganic fertilizers. In the Western Highlands, however, the use of inorganic forms of fertilization and the maintenance of soil health have neither been generally widespread nor consistent due to patterns of land use 


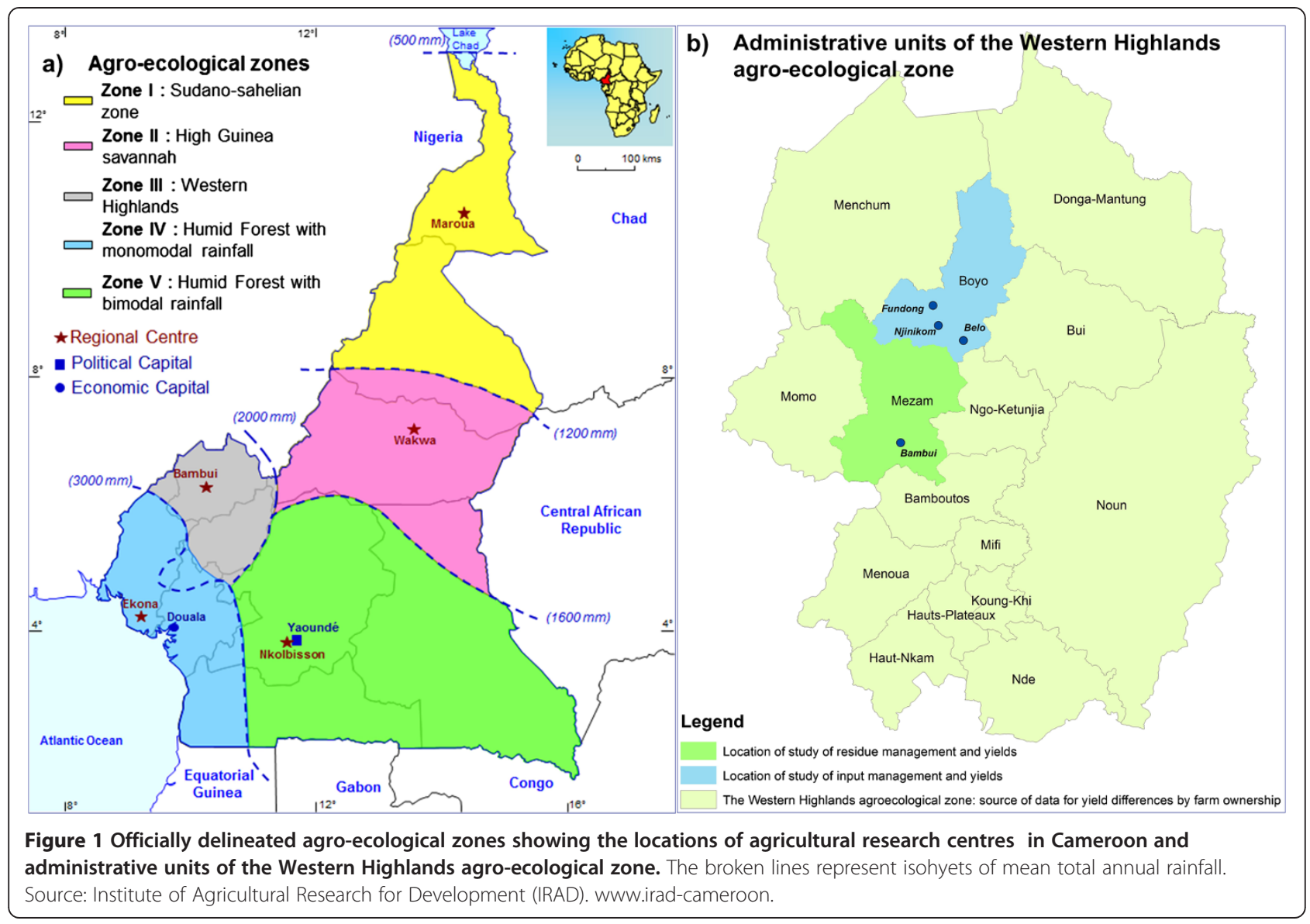

and agricultural governance. Economic constraints limit the use of inorganic fertilizers for a majority of the smallscale farmers. The limited maintenance of soil chemical and structural health has led to a general stagnation of yields for most food crops over the last three decades. Cases of reasonable yield growth per hectare for most major food crops in the region are limited, notwithstanding the large yield gaps that exist between farmers' yields and optimal yields.

\section{Socioeconomic context}

Over $80 \%$ of the active population is involved in farming. Farms are generally small in size, approximately 0.5 to 2 hectares per family. The economy of the Western Highlands agro-ecological zone relies heavily on agriculture, as there are relatively few alternative sources of employment. Notwithstanding the large proportion of the population employed by agriculture, the sector still depends heavily on traditional practices of crop cultivation and farm management. The agriculture is therefore still characterized by limited mechanization, low use of fertilizer inputs, high labor inputs, limited soil conservation strategies and the general absence of enabling infrastructure for agricultural development. Farmers still rely heavily on the use of simple tools (hoes, cutlasses, and spades) and techniques (manual weeding, hoeing and harvesting). While nearly $80 \%$ of farming households possess some form of livestock, just about $6 \%$ practice grazing of livestock as a means of livelihood. A majority of the livestock kept are poultry and small ruminants that are poorly integrated into the farming system. Land-use pressures are growing, sustained by an annual population growth rate of about 3\% in the region [12]. Such pressures are increasingly being manifested as conflicts between farmers and grazers over land rights and inter-tribal strife over farming land. Traditional land tenure laws make for unequal rights of access to landed property based on gender. This inequality has far-reaching consequences for access to other agricultural development resources for women.

\section{Research methods}

This study was part of a larger study carried out between March and September 2011. The study was carried out in three third-level administrative units of the Boyo Division. The broad goals of the larger study were follows: to measure the gap between maximum attainable yields and yields of average farms of smallholder agriculturalists; to identify and rank the main reasons for the gap between maximum attainable yields and yields on farmers' farms as perceived 
by the farmers; and to determine common land management practices or sociocultural characteristics of smallscale farmers that are associated with differences in crop yields per hectare.

This paper focuses on the third goal - determining the effects of common land management practices and sociocultural characteristics of small-scale farmers that are associated with differences in crop yields per hectare.

\section{Fieldwork data acquisition}

At the request of the researchers, a group of 36 farmers voluntarily opted to take part in a more detailed study of their farming system practices. Their selection was based on a number of factors. They had to be full-time farmers, living permanently in the community. The farmers had to be practicing food crop cultivation (not cash crops). Thirdly, they had to be willing to allow visits to their farms and to share information on farming practices, problems and other information related to food security of their households and communities. Participants were free to opt out of the study at any time by simply informing the researchers of their wishes, and were not obliged to provide any reasons for their decision. The group was made up of 11 males and 25 females with varying levels of formal education, ranging from having no formal education to pre-university-level schooling. They had an age range of between 38 and 65, and farm sizes of between 0.5 and 2 hectares.

The underlying principles guiding interactions with participants were aspects of farming system research developed in the literature on participatory farmerresearcher interaction [13,14]. These principles can be summarized into three main views. First, most farmers have an extensive knowledge of their production environment, crops, cropping practices and many of the associated constraints. Secondly, most farmers learn from their mistakes, and try out different practices that minimize their susceptibility to similar errors. Thirdly, most farmers are willing to share information on their practices and reasoning behind them when the right atmosphere of trust and respect is provided. Guided by these principles, the fieldwork and data acquisition took three forms: farm visits, observations, and interviews.

For each of the households, informal semi-structured interviews were carried out during pre-arranged visits at their homes. During these interviews, issues related to types and sources of farm inputs, influences on choices of crops cultivated, types of farming techniques used, and constraints associated with the use of these techniques were explored. Farmers were also invited to discuss issues regarding their integration into the larger context of food production, such as input and output prices, access to local and neighboring city markets, and so forth.
Farmers were accompanied at their farms through several sessions of pre-arranged visits. The researcher participated in farm-related activities such as planting, weeding and harvesting. These farm visits provided an opportunity for informal discussions on different aspects of agricultural resource use and constraints for individual households. The researcher also attended a number of meetings of farming groups of which participating farmers were members. Such attendance provided insights into the societal context of knowledge and resource sharing, as well as the appreciation of challenges to food crop production beyond the immediate household of the participating farmers. This method of active participation in the research process provides an opportunity of interweaving field observations with semi-structured interviews and open questions, which is the basis of the method known as narrative walks [15]. The goal was to derive sufficient material to unravel cause-effect relationships that determine the relationships between yields and different farming practices among smallholder farmers. Data were gathered on the following aspects of farmers' agricultural activities: use of inorganic fertilizers, animal droppings, compost, improved seeds and their associated problems and challenges; the role of factors such as gender, age and education in the choices of crops cultivated, sizes of farms, access to farm inputs, overall farm management and yields; factors affecting farm management practices such as intercropping, farm residue management, farm clearing and choices of crops cultivated; and the yield of maize (in tons per hectare) for individual farmers.

Different households presented different challenges, with some warranting more visits than others before sufficient data were derived to establish such relationships clearly. Towards the end of the study, sufficient data were gathered for 31 out of the 36 participating farmers. Five of the farmers were either unavailable to participate sufficiently in the process to permit sufficient accumulation of data on relevant topics or were not completely available due to family and other obligations.

The main crops cultivated in the study areas are maize (Zea mays), beans (Phaseolus vulgaris), potatoes (Solanum tuberosum), banana (Musa sapientum), and colocasia (Colocasia esculenta). Maize was chosen as the indicator crop for this study. The association between yields of maize and dominant farming practices has been studied because maize is by far the most important food crop of the region. Maize is the staple food crop of the community and all traditional ceremonies in which food is involved strongly depend on the maize crop. Over the last half-century, new food crops have become more common to access in the communities than they were in the past. Maize has, however, remained indisputably the main food crop cultivated and consumed by almost all faming households. 


\section{Data on farmer surveys and site studies}

Data on field surveys of small-scale agriculture and site studies of yields were derived from research-oriented development organizations in the study.

Data on yield differences between farmers practicing traditional peasant farming methods and those practicing enhanced methods were collected through Farmer Field Schools (FFSs). As informal education structures, FFSs target practicing farmers mainly (but not exclusively) in rural areas. The goal of FFSs is to provide participants with knowledge and techniques of integrated agricultural production. FFSs draw on resources of the immediate natural environment to develop tools and techniques that impart to participants a mastery of their farming system, an understanding of existing biological threats to food production within their locality, and a basic understanding of the role of the abiotic environment in plant growth and health. Training takes a hands-on and participatory approach, with farmers encouraged to build on their local knowledge and skills as they learn techniques of farm fertilization, water management, seed selection and storage, proper methods of planting, crop care and harvesting, and other vital farming skills. The study of the effects of training in FFSs was carried out by the National Programme for the Development of Roots and Tubers in different parts of Cameroon (Table 1). The National Programme for the Development of Roots and Tubers also provided the data that are used to portray yield differences based on different regimes of farm ownership and levels of management for four tuber crops (Table 2).

The experiments and resulting data on yield differences resulting from the control or noncontrol of diseases were carried out by the state-owned Institute for Research in Agriculture and Development in 2005. These data (Table 3) report yields of potato for Upper Farm, Bambui with and without fungicide treatment. Yield (sprayed) indicates potential yields, and yield loss (disease burden) is a measure of the percentage of produce that may be lost to disease in the absence of treatments - an indication of the loss that smallscale farmers with limited resources to manage such diseases may have to incur. The Institute for Research in Agriculture and Development also provided data on the effects of different regimes of residue management and fertilizer use when grown in different crop combinations (Table 4).

\section{Results}

Associating yields with farming inputs

Four main inputs are identified in the small-scale farming system in the study area. These are inorganic fertilizers, animal droppings, compost, and improved seeds. The use of these inputs is neither uniform among all farmers nor constant from one agricultural season to the next. While all farmers participating in the study admit to having used all of these inputs at one time or another, not all farmers used the different inputs within the study period.
Use of Inorganic Fertilizers

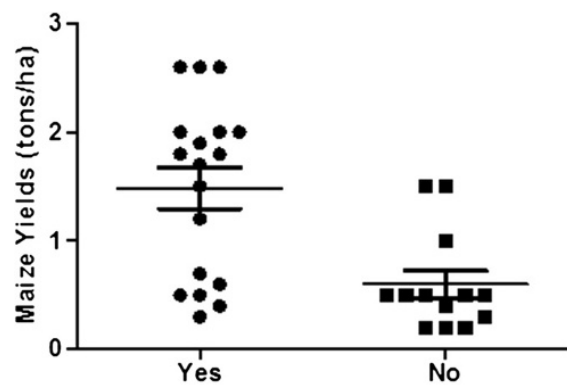

Use of Improved Seeds

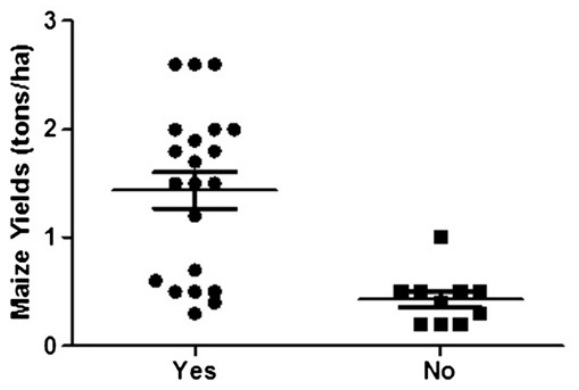

Use of Animal Droppings

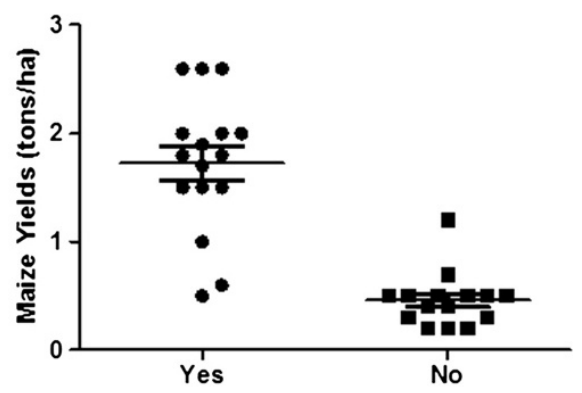

Use of Compost

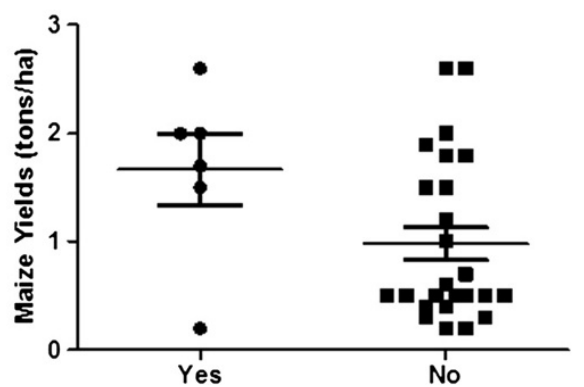

Figure 2 Association of different agricultural practices to yields of maize. The dots represent individual farmers. Error bars represent means with standard errors of means for groups of respondents. $(N=31)$. 


\section{Use of inorganic fertilizers}

The use of chemical fertilizers is associated with high mean yield increases (Figure 2). However, it must be noted that only $58 \%$ of the sampled farming population used any chemical fertilizers. Also, only about $66 \%$ of those using fertilizers were able to meet up to $50 \%$ of their fertilizer needs and about 39\% satisfied more than $80 \%$ of their fertilizer needs. While some farmers may readily admit using inorganic fertilizers, the amount used is therefore rarely sufficient to achieve optimal results. Farmers also observe that the use of inorganic fertilizers is not necessarily constant over time. The ability to purchase and use fertilizers depends on the condition of the household prior to and during the farming season. Other needs may use up limited resources during the farming period and limit or prevent the household's ability to afford fertilizers.

\section{Use of animal droppings}

Approximately $48 \%$ of sampled farmers used animal droppings, albeit insufficient in most cases (Figure 2). The use of animal droppings is shown to have the most substantial association with high yields (Figure 2). This ranking is based on comparison with the use of chemical fertilizers, improved seeds, and plant vegetal waste products. Animal wastes bring a cocktail of benefits to the poorly structured, low-nutrient soils of this region. Studies have documented such benefits $[16,17]$. Besides providing more nutrients per unit volume relative to other organic fertilizer sources, animal droppings improve the soil structure through enhancing aeration and preventing compaction. The use of animal droppings therefore helps improve the soil's moisture-retention capacity and provides room as well as favorable conditions for the growth of beneficial soil microbes [18]. Such improvements in structure, microbial composition and chemistry reduce erosion and also help to prevent nutrients from leaching. Animal wastes can be important in balancing extremes in high soil $\mathrm{pH}$ of the Western Highlands of Cameroon.

\section{Use of improved seeds}

Farmers who use improved seeds experience substantially better yields relative to those that do not use them (Figure 2). Farmers depend considerably on the quality of their seeds for viable crops and a good harvest. The traditional method of saving some of the previous harvest as seed for next year's planting has gone on for several generations in Cameroon's Highlands Region. Through such seed savings, smallholder farmers have been able to conserve many of the genetic material that has been used for several generations. Some of these genetic materials have survived different environmental challenges that the region has faced during this time. Research into seeds with higher production potential, pest resistance, drought tolerance and other beneficial traits for the region is bringing about improvements in some of the original seed stocks.

\section{Use of vegetal waste (compost)}

While the use of animal droppings may be seen as insufficient in such communities with limited access to chemical fertilizers, the use of plant residues in terms of compost is even lower. Farmers have the potential of generating appreciable amounts of vegetal waste products that can serve as inputs to farming activities through a variety of means. Vegetal matter with potential use as farm inputs can be derived from accumulated household kitchen debris and from farms after weeding and harvesting of crops. By converting these products into compost and using it on farms, farmers may reduce - and in some cases even provide all of their fertilization needs [19]. Notwithstanding efforts by local authorities and local farming organizations at promoting the production and use of compost as a cheap and reliable source of farm fertilizer, only about $19 \%$ of sampled farmers use this technology at varying degrees of intensity (Figure 2).

\section{Associating yields with dominant farming practices}

In small-scale farming systems, the methods of plant residue management and the practice of intercropping are important in determining the availability of nutrients for plant growth. Residue management here refers to the incorporation of the plant material into the soil mix either in a decomposing or burnt form with the aim of fertilizing the soil. This is an important process in cases where small-scale farmers have limited economic potential to acquire synthetic fertilizers. Intercropping, on the other hand, is the practice of growing two or more crops in proximity [20]. Intercropping is practiced for a number of reasons: as an insurance against crop failure, to reduce the proliferation of plant pests, to enable non-nitrogen-fixing plants to benefit from leguminous mixes, and to sustain a harvest variety for home consumption $[21,22]$. These two farm management techniques dominate much of the smallholder farming landscapes in Cameroon.

\section{Forms of residue management and effects on yields Burying of plant material below crop-bearing ridges}

In this case, cleared vegetation is allowed to partially decompose at the surface of the farm. The decomposed vegetation is then gathered and laid in lines that eventually serve as ridges for seasonal crops. Soil from between these lines of decomposing vegetation is used to cover them, thereby forming the ridges. The vegetation continues to decay within these ridges for another 1 to 2 months before crops are planted on them. The lines of furrows from where the soil has been taken to form ridges for one season become ridges in the next planting season when crop residues are placed in them 
and soil from previous ridges is used to cover the residue. Farmers use basic tools (hoes) to form these ridges, making it a very laborious task and limiting the scale of use to small farms usually not larger than 1.5 hectares. The use of such techniques on larger farms requires cooperative labor from family, friends, or farming common initiative groups.

\section{Localized surface burning of plant material}

This is a localized process of burning plant residue on the farm with the goal of temporarily increasing fertility on a small patch and exploiting it for particular crops. Surface burning is more predominant where plant residue is plentiful and the process of burying all of it before burning is time and labor demanding. This is the case among small-scale farmers in the equatorial regions and its fringes, where above-ground biomass is usually plentiful. Burning is also the preferred choice for clearing the farm when farmers have limited time to prepare the farms for planting before impending rains.

\section{Burying and burning of plant material (locally called ankara)}

Ankara is the process of burning dry plant residue under a thin layer of soil. Ankara is a localized process practiced mainly among small-scale farmers and may involve either one ridge or a few ridges of a farm. Even smallscale farmers with land sizes $<1$ hectare rarely practice ankara on the whole farm, because this technique is such a localized, process mainly due to the limited availability of plant residue. Farmers see it as a process of concentrating plant nutrients on limited spots to optimize their use in high nutrient-demanding crops.
When averaged over fertilizers and cropping patterns, the burning of plant residue on the surface results in $20.5 \%$ greater yields than burying, while burning underground resulted in $80 \%$ greater yields than burying of plant residue (Table 1). The burning of plant residue underground resulted in significantly higher yields when compared with other methods of residue management at all fertilizer levels (Table 1). The exception to this is when 200-120-120 nitrogen:phosphorus:potassium fertilizer is applied in cases where residue was burnt on the surface. In this case, the increase in yields of $8 \%$ is not significant. The most significant difference among residue management techniques, however, is when residue is burnt underground with no fertilizer applied. The result is a sixfold increase in yields, which is 0.867 tons/hectare for burying residue, compared with 6.283 tons/hectare for burning residue underground (Table 1). Notwithstanding the relative profitability of practicing the burning of plant material underground as a residue management technique, it cannot be adopted on a whole-farm basis for many farmers. This is because farmers cannot obtain enough plant material to produce sufficient ash yield to make a difference for the entire farm, and hence specific spots are chosen to make use of the limited ash produced from burying the limited amount of plant residue.

\section{Use of intercropping}

Intercropping is a common feature of smallholder agriculture in Cameroon. Among the farmers studied, about 94\% practice intercropping. While the crop combinations with which intercropping are practiced differ from one agro-ecological zone to the next, many characteristics of this practice are the same nationwide. Intercropping is carried out mainly on small farm sizes, generally

Table 1 Effects of residue management and fertilizer use on maize yields in different crop combinations

\begin{tabular}{|c|c|c|c|c|c|}
\hline \multirow[t]{2}{*}{ Residue management } & \multirow{2}{*}{$\begin{array}{l}\text { Fertilizer level } \\
\text { (kg/hectare) }\end{array}$} & \multicolumn{3}{|c|}{ Cropping pattern (intercropping) Yields (tons/hectare) } & \multirow{2}{*}{$\begin{array}{c}\text { Residue } \\
\text { management } \\
\text { mean }\end{array}$} \\
\hline & & Maize & Maize and colocasia & Maize, colocasia and beans & \\
\hline \multirow[t]{4}{*}{ Burying of plant material } & $0-0-0$ & 1.041 & 0.666 & 0.894 & 0.867 \\
\hline & $100-60-60$ & 5.191 & 4.395 & 3.921 & 4.502 \\
\hline & $200-120-120$ & 6.029 & 6.18 & 6.068 & 6.092 \\
\hline & Mean & 4.087 & 3.747 & 3.628 & 3.82 \\
\hline \multirow[t]{4}{*}{ Burn plant material on the surface } & $0-0-0$ & 1.754 & 1.555 & 1.166 & 1.492 \\
\hline & $100-60-60$ & 6.217 & 5.488 & 5.389 & 5.698 \\
\hline & $200-120-120$ & 7.11 & 7.399 & 5.389 & 6.633 \\
\hline & Mean & 5.027 & 4.814 & 3.981 & 4.607 \\
\hline \multirow[t]{4}{*}{ Bury and then burn plant material } & $0-0-0$ & 6.257 & 6.11 & 5.981 & 6.116 \\
\hline & $100-60-60$ & 7.593 & 7.385 & 6.943 & 7.307 \\
\hline & $200-120-120$ & 7.252 & 7.198 & 6.977 & 7.143 \\
\hline & Mean & 7.034 & 6.898 & 6.634 & 6.855 \\
\hline Cropping Pattern Means & & $5.383^{A}$ & $5.153^{A}$ & $4.748^{C}$ & \\
\hline
\end{tabular}

Coefficients of variation: residue management $=20.27 \%$, fertilizer $=12.15 \%$, cropping pattern $=10.05 \%$. LSD $_{0.05}$ residue management $=0.595$. Means in a row followed by the same uppercase superscript letter are not significantly different at the $5 \%$ level according to Duncan's new multiple-range test. Fertilizer ratios represent nitrogen-phosphorus-potassium. 
those $<2$ hectares. Most intercrop mixes contain one leguminous crop. Crops within an intercrop are selected based on their importance for household consumption the more market-oriented the farming, the less the variety of crops in the intercrop. While there are cases where food crops are intercropped with cash crops, the practice is predominantly carried out by food crop farmers.

The small size of farmland is one of the main motivations for the practice of intercropping. For a sample of 31 smallholder farmers, the mean size of the area cultivated is 0.9 hectares with a standard deviation of 0.39 . Since most of the households depend heavily on farm production for most of their food, they tend to cultivate as much variety of food as the small farm portions can support. Intercropping is therefore an important aspect of livelihood diversification with the potential of diversifying the food basket of small-scale agricultural producers. Diversification of food and income sources is critical for economically deprived rural livelihoods in this region [23].

\section{Yields and the control of diseases}

Blight is an important plant disease for food crop producers in Cameroon. A soil-borne plant infection that is common in the Adamawa, west, northwest, and southwest regions of the country, blight can also be transmitted through infected seeds. Early blight occurs between November and February (the dry season) while late blight occurs between March and October (the dry season). Blight has been reported as the most important disease accounting for the most significant losses in common food crops of this region, such as garden huckleberries, potatoes, eggplant, and tomatoes [24-26]. Yield losses caused by late blight foliage infection can reach $71 \%$ in potato, $100 \%$ in tomato and $45 \%$ in

Table 2 Mean yields (in tons per hectare) of potato with and without fungicide treatment

\begin{tabular}{|c|c|c|c|}
\hline $\begin{array}{l}\text { Clone/ } \\
\text { variety }\end{array}$ & $\frac{\text { Yield (unsprayed) }}{\text { (tons/hectare) }}$ & $\frac{\text { Yield (sprayed) }}{\text { (tons/hectare) }}$ & $\begin{array}{l}\text { Yield loss } \\
\text { (disease } \\
\text { burden) (\%) }\end{array}$ \\
\hline 391065.81 & 17.97 & 24.06 & 25.3 \\
\hline 393075.54 & 20.05 & 25.1 & 20.1 \\
\hline 393617.54 & 19.93 & 29.36 & 32.1 \\
\hline 393371.58 & 19.22 & 22.84 & 15.8 \\
\hline 395524.9 & 18.03 & 38.15 & 52.7 \\
\hline 391047.34 & 16.39 & 18.95 & 13.5 \\
\hline 392657.8 & 20.67 & 21.1 & 2 \\
\hline 391580.30 & 14.98 & 19.78 & 24.3 \\
\hline 391065.69 & 16.25 & 26.53 & 38.7 \\
\hline 393349.68 & 15.14 & 16.53 & 8.4 \\
\hline
\end{tabular}

Yield (unsprayed), no disease control; yield (sprayed), yields in which diseases are controlled; yield loss, measure of the percentage of produce that is lost to disease in the absence of treatment. garden huckleberry [27]. Potato tubers in storage can also be susceptible to blight when they are harvested from infected soils $[24,26]$. Tests on 10 common potato varieties at Upper Farms, Bambili show a mean yield loss from the burden of disease of $23.3 \%$ with a median of $22.2 \%$ and standard deviation of $14 \%$ (Table 2). Access to knowledge and resources to contain blight infection can therefore greatly determine the gap between optimal yields and disease limited yields.

\section{Yields and the sociocultural dimension of households}

\section{Gender perspectives of yields}

The mean yield from male-managed farms is 1.8 tons/hectare of maize relative to just below 1 ton/hectare from female-managed farms (Figure 3a). The mean yield of 1 ton/hectare for female-managed farms has to be appreciated within the context of the overall data spread: about $60 \%$ of female farmers have yields that are at or below the 25th percentile (Figure 3a). These lower yields on femalemanaged farms are a reflection of the differences in factors of agricultural production (inputs and management) between genders. More than $85 \%$ of males used inorganic fertilizers in crop production, relative to about $54 \%$ of females (Figure 4). Also, males on average provided up to $60 \%$ of the optimum fertilizer needs for their farms while females provided approximately 30\%. Such differences are also found in the use of other inputs and techniques that do have positive effects on crop yields, such as the use of compost, improved seeds, and animal droppings (Figure 3b).

Problems faced by women in Cameroon's agriculture are very much akin to those faced by women in the rest of subSaharan Africa. Women share the burden of farm work in most households, yet they hold fewer agricultural assets such as farm tools and equipment of diverse farm-related activities than their male counterparts $[28,29]$. The traditional gender division of labor can also serve to explain the differences in crop yields between males and females. In Cameroon there is a gender division of labor that ascribes the roles of childcare and household care to women $[30,31]$. These roles are time consuming, thereby reducing the availability of women for activities that may improve their performance in agriculture such as the preparation of compost or collection or animal droppings. Another aspect of the gender division of labor in the agricultural sector is in the types of crops cultivated by male and female farmers [30]. In the North West region, men predominantly cultivate traditional cash crops such as coffee, bananas and a variety of fruits, while women cultivate staple food crops principally for household consumption. While men readily derive income from the sale of their produce, a portion of which they can reinvest on their farms, women can only sell if surpluses persist after household consumption. 


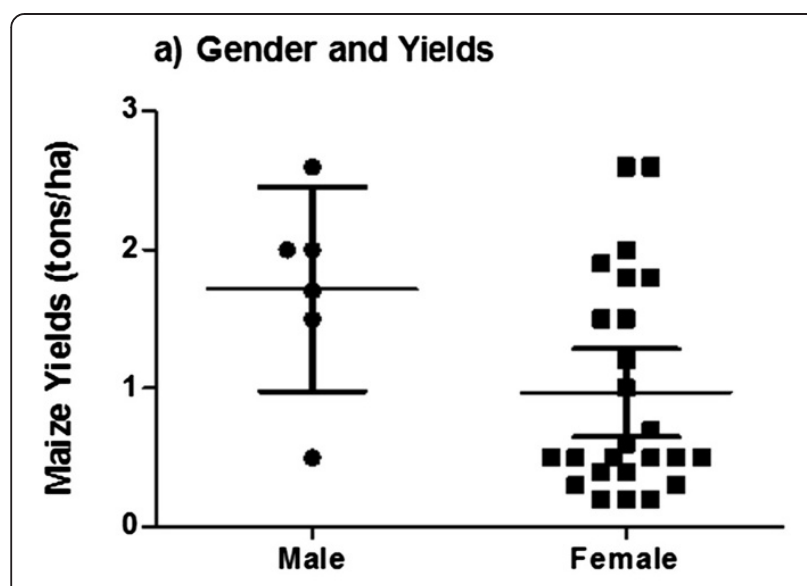

b) \% Fertilizer Needs Met

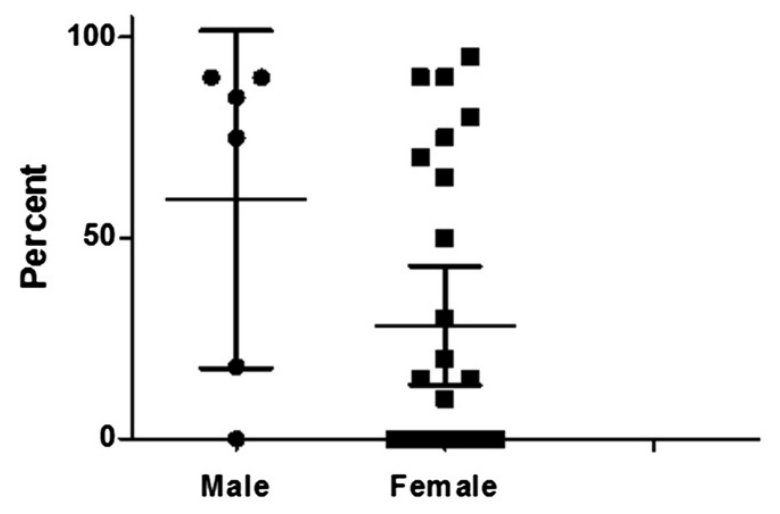

c) Area Cultivated

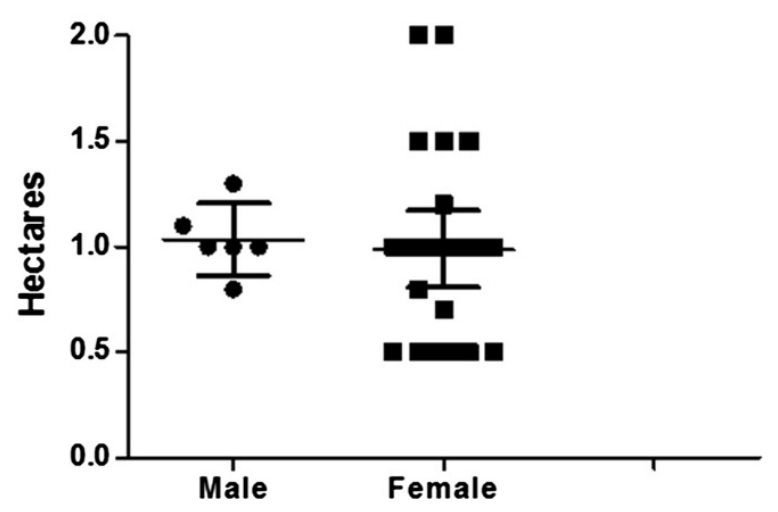

Figure 3 Yields and gender in food crop production: (a)

Association of gender and yields of maize, (b) Association of gender and the percentage of fertilizer need met, (c) Association of gender and area cultivated. Dots represent individual farmers. $\mathrm{F}=$ Female and $\mathrm{M}=$ Male. Error bars represent means with 95\% confidence intervals for different groups of respondents $(N=31)$.

\section{Yields and level of education}

An association exists between having some level of education and yields. While the difference between having a post-secondary school level education and an elementarylevel education is minimal, the difference between A-level

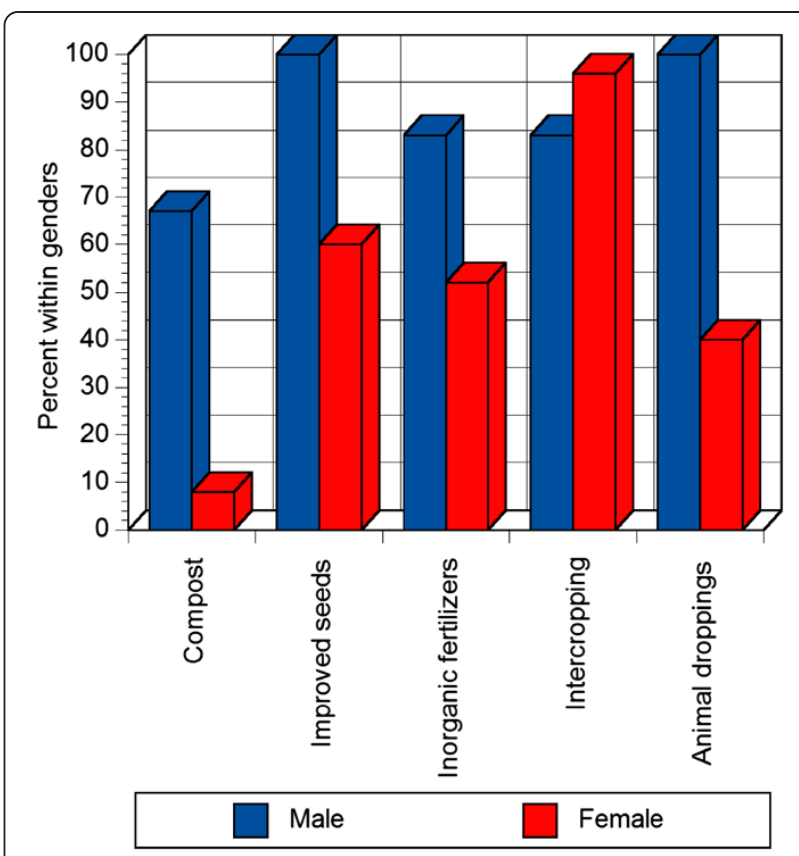

Figure 4 Percentage of individuals that used different farming inputs and techniques within different genders. Males, $n=6$; females, $n=25$.

and no education is considerable (Figure 5). Also considerable is the difference between no education and elementary education (Figure 5). In the group of farmers studied, approximately $23 \%$ had received advanced formal education (post-secondary), $25 \%$ had elementary education and $52 \%$ had received no education. The data show some relationship between having some level of education and the use of inputs such as animal droppings, improved seeds and fertilizers. This may be because education enables farmers to access information on the potential benefits and drawbacks of available technologies. Farmers with some level of education tend to be more willing to test and adopt yield improvement technologies [32]. These farmers may therefore be in a position to distinguish more readily between what would provide better returns for their investments in labor or capital for different options at their disposal.

In Figure 5 the differences in yields between farmers that have undergone formal education and those who have not is less substantial than it is for other variables (such as the use of fertilizers, improved seeds, animal droppings). This inequality may be explained by other more subtle differences, such as the accumulated farming experience among older uneducated farmers. Older farmers can draw on their long years of farming experience in the region in managing a number of production constraints such as crop pests, nutrient conservation, incidences of dry spells and seed selection. 


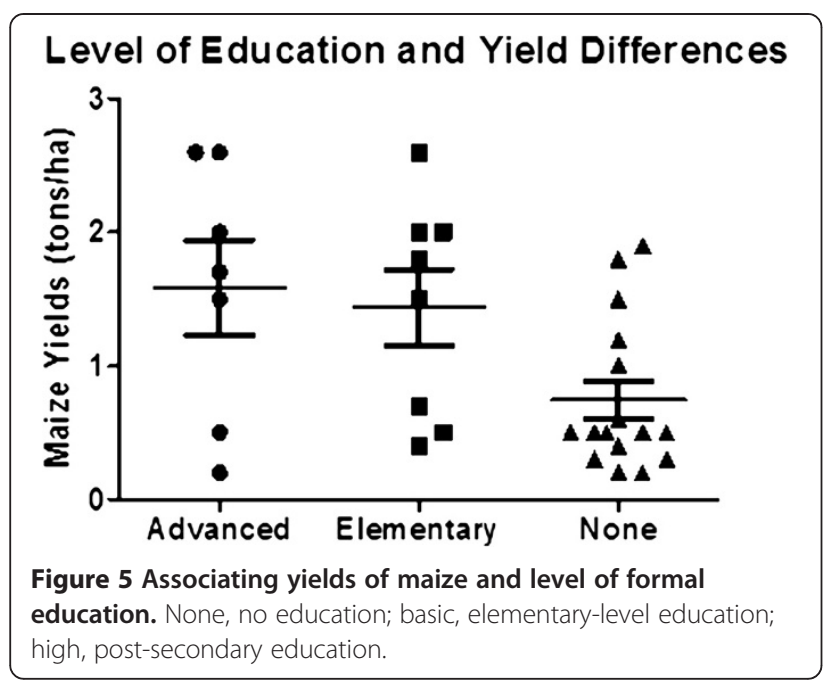

Education that can have a meaningful impact on agricultural productivity may not necessarily be formal. Opportunities for learning and skills development, such as FFSs, can make a difference. Farmers that have undergone some informal training in farming (through FFSs) will generally obtain significantly higher yields than those that have not (Table 3). Cases where farmers using traditional nonoptimized farming methods can yield more than those with trained skills, such as is the case in Lobo, are uncommon (Table 3). FFSs have proven to lead to significant positive outcomes with regards to food production per hectare, the adoption rate of new technologies and agricultural income [33].

Yields in relation to farm ownership and level of farm management

Yield differences are mirrored in the system of farm ownership and management (Table 4). Generally, low yields are associated with female-managed farms. Farms owned by female common initiative groups and male-managed farms produce intermediate to high levels of yields. Young farmers with specialized (not necessarily formal) training in food crop cultivation produce the highest yields (Table 4). The system of farm management can be divided into four levels: level 1, with limited inputs including poorly sourced planting material and dominantly traditional farming methods; level 2, with locally sourced soil improvement inputs (compost, manure) and planting materials with basic traditional farming methods; level 3, with moderate soil improvement inputs (fertilizers, compost, and manure) including planting material from specialized sources, improved farming methods, and limited or no control of diseases; and level 4, with optimal soil improvement inputs (fertilizers, compost, and manure) and planting materials from specialized sources, improved farming methods, and control of diseases.

The low yield from female-managed farms is also associated with low levels of management, while malerun farms receive high levels of management and are consequently associated with high yield outputs (Table 4). Worthy of note is the fact that, at the same levels of management, farms of female common initiative groups are associated with higher yields than individual femalemanaged farms. In this case, these differences can be explained by two main reasons. Firstly, collaboration towards a common cause by female common initiative groups entails mobilizing greater inputs of labor to tackle farming chores in a timely and efficient manner. This collaboration also means that the deficiencies of individuals within the group can be supplemented by the strengths of other members during the farming process. Increasingly, national agricultural development institutions have tended to appreciate the role of common initiative groups and cooperatives in fostering food production at grassroots level.

Table 3 Yield differences between farmers using traditional peasant farming techniques and those using integrated farming techniques developed at Farmer Field Schools (FFSs)

\begin{tabular}{lcc}
\hline Location & \multicolumn{2}{c}{ Mean yield (tons/hectare) } \\
\cline { 2 - 3 } & Peasant practices & FFSs integrated practices \\
\hline Nyalla & $17.9( \pm 4.07)$ & $46.9( \pm 3.51)$ \\
\hline Mbalangi & $23.1( \pm 3.17)$ & $26.3( \pm 3.29)$ \\
\hline Bali & $13.5( \pm 2.73)$ & $15.8( \pm 2.51)$ \\
\hline Bilik & $29.5( \pm 3.84)$ & $45( \pm 3.79)$ \\
\hline Lobo & $43.7( \pm 2.95)$ & $23.6( \pm 2.77)$ \\
\hline Andom & $52.2( \pm 3.25)$ & $74( \pm 3.52)$ \\
\hline Timangolo & $43.2( \pm 1.94)$ & $56( \pm 2.11)$ \\
\hline Meiganga & $8.1( \pm 1.54)$ & $33.1( \pm 2.09)$ \\
\hline Bemboyo & $11.9( \pm 3.11)$ & $45.6( \pm 2.61)$ \\
\hline
\end{tabular}

*Minimally significant difference. ${ }^{* *}$ Significant difference. ${ }^{* *}$ Highly significant difference. NS, nonsignificant difference. 
Table 4 Yield differences by farm "ownership" and management system for major tubers in Cameroon's Western Highlands agro-ecological zone

\begin{tabular}{|c|c|c|c|}
\hline Crop & Yield (tons/hectare) & Percentage of farms & Dominant system of farm ownership and management level \\
\hline \multirow[t]{5}{*}{ Cassava } & 1 to 2 & 37 & Female-managed farms [1] \\
\hline & 2.1 to 4 & 13 & Female-managed farms [2] \\
\hline & 4.1 to 5 & 14 & Farms of women's common initiative groups [2] \\
\hline & 5.1 to 6 & 31 & Both female-managed and male-managed farms [3] \\
\hline & 6.1 to 10 & 5 & Male-managed farms; farms of women's common initiative groups [4] \\
\hline \multirow[t]{4}{*}{ Yam } & 1 to 2 & 10 & Female-managed farms [1] \\
\hline & 2.1 to 4 & 3 & Female-managed farms [2] \\
\hline & 4.1 to 6 & 5 & Farms of women's common initiative groups [2] \\
\hline & 6.1 to 10 & 82 & Farms of young males, trained, dynamic and specialized [4] \\
\hline \multirow[t]{5}{*}{ Sweet potatoes } & 1 to 2 & 9 & Female-managed farms [1] \\
\hline & 2.1 to 5 & 12 & Female-managed farms [2] \\
\hline & 5.1 to 7 & 17 & Farms of women's common initiative groups [2] \\
\hline & 7.1 to 12 & 48 & Farms of male and female common initiative groups [3] \\
\hline & 12.1 to 30 & 24 & Farms of young males, trained, dynamic and specialized [4] \\
\hline \multirow[t]{5}{*}{ Solanum potatoes } & 5 to 9 & 43 & Female-managed farms [1] \\
\hline & 9.1 to 19 & 13 & Both female-managed and male-managed farms [2] \\
\hline & 19.1 to 25 & 15 & Both female-managed and male-managed farms [3] \\
\hline & 21.1 to 30 & 14 & Male-managed farms and farms of women's common initiative groups [3] \\
\hline & $>30$ & 15 & Farms of young males, trained, dynamic and specialized [4] \\
\hline
\end{tabular}

\section{Choice of crops to cultivate and implications on yields}

The process of decision-making in households on types of food crops to plant is very complex. Mapping out the complete system interaction of variables associated with decision-making on the choice of crops that farmers decide to grow at each time may be very challenging. However, it is possible to identify the main factors that are considered before these decisions are made (Figure 6). An understanding of these factors is important in revealing the motivation for cultivation of different crops. Given the heavy dependence of small-scale farmers on natural factors for agricultural production, one may expect to find that where agro-ecological suitability for the cultivation of a particular crop drives its production, the

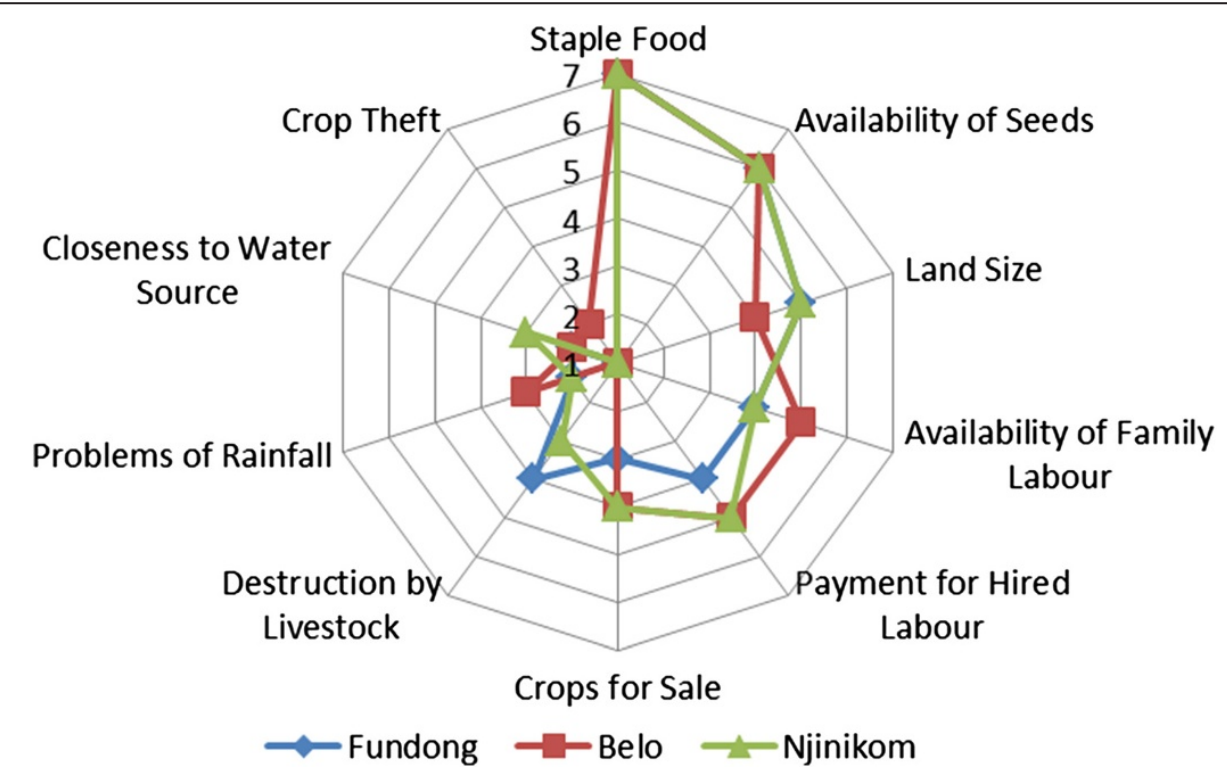

Figure 6 Farmers' ranking of main factors considered before deciding which types of food crops to cultivate. $1=$ lowest rank, $7=$ highest rank. 
gap between maximum attainable yields and farmers' yields is likely to be smaller. On the other hand, where cultural demands predominate over agro-ecological suitability in farmers' decisions about which crops to cultivate, the gap between maximum attainable yields and farmers' yields is likely to be larger. Figure 6 shows a strong influence of cultural demands on the choice of crops that are cultivated. The cultivation of crops because they constitute the staple food ranks highest in farmers' consideration when they make decisions on which crops to cultivate (Figure 6). The basis for estimating the yield gap based on agro-ecology and culture as major drivers of the choice of crops cultivated is dependent on the assumption that there is little or no yield-enhancing input in agriculture. This assumption is true for a majority of smallholder farmers in Cameroon, as it is for most regions of West Africa and Central Africa [34].

Other important factors determine farmers' choice of crops and are neither directly cultural nor agro-ecological. These factors tend to be more economic and social in nature. They include the availability of seeds, the size of agricultural land, payment for hired labor, the availability of family labor, destruction by livestock, crop theft and the cultivation of crops primarily for sale (Figure 6). Important to note is that, at the very grassroots of rural smallholder production, the farming of food that is staple for household consumption remains the main driver of choice for crops to cultivate (Figure 6). Being a household staple food is the most important consideration, ranked highest at seventh on a 7-point scale relative to agro-ecological considerations such as closeness to water source and problems of rainfall, ranked second and third on a 7-point scale (Figure 6). Other agro-ecological considerations such as problems of pests and soil suitability do not feature in farmers' lists of considerations.

\section{Discussion}

The challenge to access and use of inorganic fertilizers

The main impediment to fertilizer use among smallholder farmers is its high cost. Access to the right quality of fertilizers in sufficient quantity is therefore beyond the reach of many smallholder farmers. Fertilizer prices have been increasing steadily since 1967 (Figure 7). These general trends hide some inter-annual price variations that have had serious consequences for food crop production on an annual basis. Within 1 year, from 2007 to 2008, muriate of potash $(\mathrm{KCl})$ diammonium phosphate $\left.\left(\left(\mathrm{NH}_{4}\right)_{2} \mathrm{PO}_{4}\right)\right)$ witnessed an increase of more than $153 \%$. In the same light, diammonium phosphate experienced a $146 \%$ price increase in the 5 months from February to June 2008 [35]. The low fertilizer use rates in countries of subSaharan Africa are seen to be ineffective for sustaining soil fertility and crop growth [36,37]. This is considered one of the main reasons for the stagnation of agricultural growth in sub-Saharan Africa over the last 40 years $[36,38,39]$.

Fertilizer use has the potential to improve income from farming and to enable farmers to become less vulnerable to crop failures and food shortages. Since the 2008 food price crisis, the Government of Cameroon has initiated a number of initiatives aimed at making inorganic fertilizers more affordable to smallholder farmers through price subsidization. Fertilizer subsidies are seen to be a less reliable and less sustainable approach to meeting national and regional soil improvement goals for a number of reasons. Besides preventing the development of competitive markets, fertilizer subsidies create fiscal burdens on states in the developing world that may already have a number of economic challenges to contend with [36,40]. During the 2010 Ebolowa AgroPastoral Show (a national agricultural event to showcase

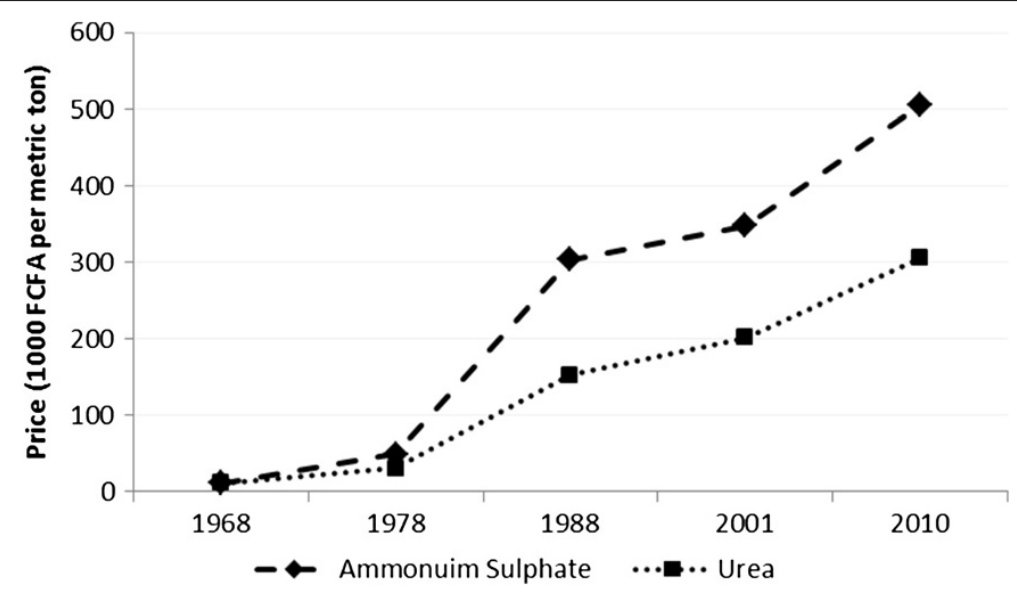

Figure 7 Real retail prices per metric ton of two main fertilizer types used in Cameroon. Real prices are derived by adjusting for inflation, using 1990 as the base year. Data from 1968 to 2001 are derived from FAOSTAT, accessed in February, 2012. Data for 2010 is derived from fieldwork interviews, carried out in September, 2011. 
the country's potentials and revisit its challenges), the government committed itself to increasing farmers' accessibility to inorganic fertilizers by creating a favorable environment for private investment in this sector. A more long-term development of the national capacity to supply the country's fertilizer needs can greatly change the pace of food crop production, especially if combined with the improvement of delivery infrastructure. Providing an enabling environment for meeting the country's fertilizer needs is seen to be a more sustainable alternative to subsidies [40].

\section{Constraints on optimizing the adoption and use of organic fertilizer alternatives}

In the face of prohibitive prices of inorganic fertilizers, attempts at different levels have been made to harness the organic fertilizer potential of small-scale farming systems to improve yields. While farmers recognize that the soils are generally poor and that the use of organic fertilizer sources such as animal droppings and waste plant residue could be beneficial in improving soil organic matter, the adoption and use of these technologies is neither consistent nor optimized. This may be explained by the level and system of integration of livestock rearing and food crop production. The system of animal rearing is practiced in a loose mixed-farming system that does not optimize the process of collecting droppings. This farming system does not functionally integrate livestock rearing to food crop production. Livestock is left to range free during the noncultivation period and is tethered outside the compounds in the cultivation season. The grazing of animals on farms to take advantage of post-harvest crop residue is not systematic. This lack of system is partly explained by the small farm sizes, which cannot sustain grazing beyond a few weeks during the 4 months of the noncropping season, and the practice of harvesting some crop parts with fodder potential (such as maize stalks) for household use as a supplementary fuel source. Grazing animals on a free range basis reduces the potential for gathering droppings and using them as farm fertilizer. The labor demands for adopting and using these technologies are therefore not encouraging for smallholder farmers [18]. In the same light, the use of crop residue-based fertilizers is challenged by the system of small-scale farming. The bulkiness of the material and its implied associated cost of transportation to farms seem to discourage wide adoption of this means of fertilization [41]. By combining sensitization with access to transport infrastructure in terms of farm-to-market roads, optimal results may become more feasible [42]. To obtain optimal adoption and use of animal-based and crop-based fertilizer alternatives, increased sensitization is important but not sufficient. Redesigning small-scale farming systems to optimize livestock-food crop interactions and linkages may have to be improved $[19,43,44]$. Also, improvements in local delivery systems, in terms of farm inputs, can be beneficial.

\section{The role of efforts at improving seed quality}

Good quality seeds as an input into small-scale farming systems have proven to be instrumental in yield improvements. The replacement of traditional varieties of the world's most consumed cereals, in association with improved farm management practices, was instrumental in driving and sustaining the Asian Green Revolution [39]. In 2005 the Support Program for Production and Distribution of Seeds and Planting Materials (PAPDIMAV) was put forward by the Government of Cameroon to enhance farmers' access to better quality seeds [12]. Together with the state institution in charge of agricultural research (the Institute for Research in Agriculture and Development), the government trains and provides materials to stimulate local interest in producing and selling high-quality seeds at affordable prices to smallholder farmers. Such seed production at a local level provides income to households engaged in seed production, but also encourages the use of higher quality seeds for food production among food crop farmers.

The challenge is not only to develop and disseminate new seed varieties that increase yield per hectare [3]. Such an approach failed with maize seeds in Ghana and Cameroon in the 1990s [32]. Rather, varieties should respond to local socioeconomic and cultural demands such as taste and storage potential. To be sustainable, varieties also have to respond to growing environmental challenges in this area such as longer dry spells, nutrient use efficiency, demand for crops and stability of yields. Such socioeconomic and environmental challenges are not static, but change with time. While important, the private sector is insufficient in guaranteeing a sustainable long-term solution for a viable seed sector in Cameroon, given the present level of socioeconomic and technological development. Also, the policy framework for integrating input markets and output markets is beyond the direct scope of influence of smallholder farmers and demands state-level intervention. The development of better input markets and delivery systems for new technology, extension services and information can only translate to improvements in food production, food security and livelihoods when combined with reliable commodity markets for farmers' produce.

\section{Vulnerability to agricultural pests and diseases can perpetuate a cycle of low yields}

With small surplus margins, farmers tend to safeguard against crop pests and diseases through practices such as intercropping. One of the main reasons for practicing 
intercropping is to minimize the potential of total crop failure that may result from infestation by pests. Crop pests have constantly been a feature of agro-ecological systems, and farmers in different parts of the world have developed a wide variety of strategies for coping with them. Losses from crop pests are currently estimated at about $16 \%$ of crop production worldwide [45]. Such losses can be particularly important to small-scale farmers in poor parts of the world, given their limited surplus margins. With global climate changing, studies have identified the emergence of new patterns for the distribution of crop pests around the world [46]. An increasing fear is that climate change may indirectly exacerbate future food security and the stability of food supplies through this new pattern of distribution of pests and diseases $[6,47]$. The need to optimize surveillance on the emergence of crop diseases and the development of optimal disease management strategies based on future climate scenarios have been urged $[1,46]$. Such strategies may include the development of disease-resistant crop strains; adapting and optimizing farming methods and systems that minimize the proliferation of pests; providing access to sustainable pest management strategies; and developing affordable tools and systems of crop protection [3,48]. In the absence of such strategies, food production and security for subsistence farmers in marginal environments, such as sub-Africa and Asia, who cannot afford expensive crop protection chemicals may be severely threatened by climate change [1].

\section{The indispensable need to fix the gender situation within small-scale farming systems}

There has been an encouragement for the inclusion of elements of gender into the framework of systems to support the development of Africa's Green Revolution [38]. Through a number of projects in the National Strategy for the Development of Agriculture and the Rural Sector, the Government of Cameroon is attempting to address elements of gender inequality in access to resources for agricultural development [12]. These projects have increased women's access to a number of inputs that would otherwise not have been available to them. Projects such as the Support Program for Agricultural Organizations (PAOPA) and the Project for Capacity Building of Communities (PRCCOM) have revitalized local-level cooperation between women within their common initiative groups and cooperatives [12]. Cooperation has also been invigorated between such groups and beneficial governmental as well as nongovernmental organizations. Thanks to such cooperation and related innovations, women are increasing their surpluses and increasingly incorporating market-oriented dimensions into their farming activities [30]. However, in other important domains, such as access to landed property and titles, the gender bias still prevails, especially in rural areas.

\section{Implications for food security in sub-Saharan Africa}

Studies have emphasized the need for major changes in the global food system in order to meet the twin challenges of feeding a growing world population with changes in dietary preferences while simultaneously minimizing the environmental footprint of agriculture on the earth's natural life-support systems $[3,49,50]$. Without concerted efforts and resources, the potential for attaining the first Millennium Development Goal namely that of halving global poverty by 2015 - is estimated to be unattainable in sub-Saharan Africa, where approximately 239 million people are estimated to be suffering from hunger and malnutrition [3]. In most of sub-Saharan Africa, where the gap between actual crop yields and potential yields remains large, the potential for agricultural productivity growth is considerable. The per-capita growth rate of agricultural gross domestic product was negative in the 1980s and 1990s for many African countries [39]. Some improvements have been noted since 2000, albeit gained from the expansion of cultivated land for major food crops $[39,51]$. This study shows that small changes in the system of food production could have considerable outcomes on yield per hectare and hence overall productivity of small-scale farming systems. The concept of sustainable intensification suggests that productivity can be improved by making better use of existing resources (even at local-level small-scale farm production systems) [50]. The data support the supposition that increasing the adoption and optimizing the efficiency of simple farming practices such as the use of compost and animal droppings can make a difference in household farm yields (Figure 2).

While it is important to examine the role of all components of food security (availability, access, stability and utilization) in achieving this first Millennium Development Goal, improving food production (the availability component) for the African small-scale farmer remains one of the biggest and most important challenges. This is because low levels of agricultural productivity are at the root of the problems of food security in sub-Saharan Africa $[3,52,53]$. The provision of food aid has been the most common response to problems of food shortages increasingly being experienced in the continent. Such short-term measures must not be forgone for long-term, more sustainable strategies for attaining higher levels of food security. The prioritization of policies that provide farmers with access to food production training, local and regional markets, as well as access to affordable farm inputs such as fertilizer and improved seed, has the potential to enable farmers to grow food to feed themselves, to sell surpluses and to diversify into high-value crops that enable them to break the poverty trap [53,54]. The place for and role of agriculture as a foundation and engine for economic growth has been intensively scrutinized and appreciated 
by scholars since the early works of Boserup [55-57]. Today, the African continent seems to offer significant potential for agricultural development. Such potential includes the following. First, a large consumer base powered by a rapidly growing population. This includes a growing middle class that is increasing the demand for quantity and variety of food to be produced. Another potential is a large yield gap that can be reduced or closed. These yield gaps for major food and fiber crops offer potentials for higher returns to agricultural investments in terms of yield growth that is presently not available in most parts of the world. Finally, there is an emergence of the understanding that the role of structural adjustments from the late 1980s and 1990s may not have been properly applied to agriculture. This is demonstrated in the new agricultural development plans that have emerged and are being implemented in a number of African countries such as Cameroon [12,58] and Ghana [59] since 2000.

For the small-scale farmer at local level in subSaharan Africa, tapping into the above potentials for agricultural development is fraught with a number of challenges. Among others, these challenges include: rising costs of farm inputs and resources that support the growth of agricultural industries such as fuel and other petroleum products, fertilizers and transportation; competition of locally produced agricultural products with cheaper alternatives from subsidized European Union and North American producers; the growing phenomenon of large-scale agricultural land acquisitions - investors and governments from industrialized countries are seizing productive agricultural lands for their own purposes; and an agricultural development environment that is more challenging than it was when other regions underwent most of their agricultural revolutions - increasingly prevalent droughts and floods in the Sudan-Sahel, changes in seasonal precipitation patterns and cases of large-scale pest infestation of major food crops.

\section{Conclusion}

At the local level, crop yields in small-scale farming systems are determined by a number of factors. These include inputs to agriculture, techniques of crop cultivation and sociocultural characteristics of farming households. These factors work in unison to determine yield levels in a number of ways. Yield differences among farming households are associated with the use of some basic inputs and practices. By proliferating and optimizing these technologies, so that more farmers can use them more efficiently, the productivity of many farming households can be improved. Other technologies such as inorganic fertilizers and improved seeds are used in small-scale local settings (albeit neither widely nor optimally) and contribute to yield differences among farmers. The production of these technologies (especially inorganic fertilizers) and their market dynamics are beyond the control of small-scale farmers at local level. While the use of inorganic fertilizers can be essential in replenishing macro-nutrient deficiencies among many nutrient-poor tropical soils, access to them is constrained by high financial costs for small-scale farmers. Being a human-managed system (and in most parts of subSaharan Africa, a cultural activity and space), the socioeconomic dimension of food crop production is as important as the management dimension. A key factor in this dimension is the place for and role of women in food crop production among small-scale farming communities. Achieving and sustaining food security in the long run will not be feasible without addressing the gender imbalance in access to land rights, agricultural inputs and investment opportunities. Such initiatives can be complemented by the import of agricultural production skills at the local scale through available technologies and tested processes.

\section{Abbreviations}

FFS: Farmer Field School.

\section{Competing interests}

The author declares that he has no competing interests.

\section{Acknowledgements}

This work would not have been possible without the kind contribution of many. Mr Ayeah Amos was instrumental in organizing farmers for the participatory studies and used his decades of experience in the region to clarify many questions regarding general aspects of the local farming system in the study area. Initial contacts with the farmers and farming groups in the study region were arranged through the Belo Rural Development Project's administrator, Mr Chiamba Enock Ntam. Mrs Mary Kenji provided results of surveys carried out by the National Programme for the Development of Roots and Tubers (used to construct Tables 3 and 4). Dr Njualem DK provided data from the Institute for Research in Agriculture and Development studies on crop residue management (Table 1) and his work with potato clones (Table 2). Their support has been priceless and highly appreciated. This research was carried out within the framework of the Linnaeus Centre LUCID (Lund University Centre of Excellence for Integration of Social and Natural Dimensions of Sustainability). The author gratefully acknowledges the financial support to LUCID from the Swedish Research Council Formas. The fieldwork was partly funded by research grants from The Swedish Society for Anthropology and Geography. The author sincerely thanks two anonymous reviewers for their helpful comments and suggestions on the manuscript.

Received: 26 July 2012 Accepted: 9 October 2012

Published: 1 December 2012

\section{References}

1. Schmidhuber J, Tubiello FN: Global food security under climate change. Proc Natl Acad Sci U S A 2007, 104:19703-19708.

2. Battisti DS, Naylor RL: Historical warnings of future food insecurity with unprecedented seasonal heat. Science 2009, 323:240-244.

3. Sasson A: Food security for Africa: an urgent global challenge. Agric Food Security 2012, 1:1-16.

4. Lobell DB, Cassman KG, Field CB: Crop yield gaps: their importance, magnitudes, and causes. Annu Rev Environ Resource 2009, 34:179-204.

5. Yengoh GT, Tchuinte A, Armah FA, Odoi JO: Impact of prolonged rainy seasons on food crop production in Cameroon. Mitig Adapt Strat Glob Chang 2010, 15:825-841

6. Beddington J: Food security: contributions from science to a new and greener revolution. Philos Trans R Soc B Biol Sci 2010, 365:61-71. 
7. Branca G, Tennigkeit T, Mann W, Lipper L: Identifying Opportunities for Climate-xmart Agriculture Investments in Africa. Rome, Italy: Food and Agriculture Organization of the United Nations; 2012:132.

8. Rockstrom J, Karlberg L, Wani SP, Barron J, Hatibu N, Oweis T, Bruggeman A Farahani J, Qiang Z: Managing water in rainfed agriculture - the need for a paradigm shift. Agric Water Manage 2010, 97:543-550.

9. Misselhorn A, Aggarwal P, Ericksen P, Gregory P, Horn-Phathanothai L, Ingram J, Wiebe K: A vision for attaining food security. Curr Opin Environ Sustain 2012, 4(1):1-17.

10. Yengoh GT, Hickler T, Tchuinte A: Agro-climatic resources and challenges to food production in Cameroon. Geocarto Int 2011, 26:251-273.

11. ISRIC: World Reference Base for Soil Resources. United Nations International Soil Reference Information Centre. Rome, Italy: Food and Agriculture Organization of the United Nations; 1998.

12. MINADER: Stratégie de Développement du Secteur Rural (SDSR), synthèse du Volet Agriculture et Développement Rural. In Stratégie de Développement du Secteur Rural (SDSR), synthèse du Volet Agriculture et Développement Rural. Yaoundé, Cameroun: MINADER; 2006:57.

13. Bellon MR: Participatory Research Methods for Technology Evaluation: A Manual for Scientists Working with Farmers. Mexico City: Cimmyt; 2001, International Maize and Wheat Improvement Center (CIMMYT); 104.

14. Van de Fliert E, Braun AR: Conceptualizing integrative, farmer participatory research for sustainable agriculture: from opportunities to impact. Agric Hum Value 2002, 19:25-38.

15. Jerneck A, Olsson L: More than Trees: Contextualising Agro-forestry and Identifying Opportunities in Subsistence Farming. Yaoundé, Cameroun: Internal report: The World Agroforestry Centre (ICRAF) West and Central Africa (WCA); 2007.

16. Kizza S, Totolo O, Perkins J, Areola O: Analysis of persistence soil nutrient status in abandoned cattle kraals in a semi arid area in Botswana. Sci Res Essays 2010, 5:3613-3622.

17. Omotayo O, Chukwuka K: Soil fertility restoration techniques in sub-Saharan Africa using organic resources. African J Agric Res 2009, 4:144-150.

18. van Schöll L, Nieuwenhuis R: Soil Fertility Management. Wageningen: Agrodok 2, Agromisa Foundation; 2004

19. Dongmo A, Vall E, Lossouarn J, Dugué P, Njoya A: Who Owns the Plant Biomass? Designing a Process of Co-management of Crop Residues for Cattle and Soils in Sudano-Sahelian Africa. Vienna (Austria): 9th European IFSA Symposium; 2010.

20. Sullivan P: Intercropping Principles and Production Practices. Arkansas, USA Appropriate Technology Transfer for Rural Areas (ATTRA); 1998:12.

21. Saka J, Adeniyan O, Akande S, Balogun M: An economic evaluation of intercropping African yam bean, kenaf and maize in the rain forest zone of Nigeria. Middle East J Sci Res 2007, 2:1-8.

22. Khan Z, Pickett J, Wadhams L, Muyekho F: Habitat management strategies for the control of cereal stemborers and striga in maize in Kenya. Int J Trop Insect Sci 2001, 21:375-380.

23. Elmqvist $\mathrm{B}$, Olsson L: Livelihood diversification: continuity and change in the Sahel. GeoJournal 2006, 67:167-180.

24. Fontem D, Olanya O, Njualem B: Reaction of certain solanaceous and asteraceous plant species to inoculation with Phytophthora infestans in Cameroon. J Phytopathol 2004, 152:331-336.

25. Fontem D: Quantitative effects of early and late blights on tomato yields in Cameroon. Tropicultura 2003, 21:36-41.

26. Martin C, Njualem D: Development of Potato (Solanum Tuberosum) Varieties with Resistance to Late Blight (Phytophthora infestans) for the Highlands of Cameroon. Accra, Ghana: ISHS Acta Horticulturae 380: Symposium on Tropical Root Crops in a Developing Economy; 1991:514.

27. Fontem D, Songwalang A, Berinyuy J, Schippers R: Impact of fungicide applications for late blight management on huckleberry yields in Cameroon. African Crop Sci J 2004, 11:163-170.

28. Kumar SK, Delgado Cl, Blackie MJ: Women's Role and Agricultural Technology. In Accelerating food production in Sub-Sahara Africa. Edited by Mellor JW. Baltimore, Maryland: John Hopkins University Press; 1987:135-147.

29. Bird K: Asset Inheritance and the Intergenerational Transmission of Poverty. London, UK: Paper presented at the CRPC/ ODI Roundtable 'Inheritance and the Intergenerational Transmission of Poverty', ODl; 2010. ODI.

30. Sikod F: Gender Division of Labour and Women's Decision-making Power in Rural Households in Cameroon: Africa Development: 2007:58-71.
31. Fonjong LN, Mbah F: The fortunes and misfortunes of women rice producers in Ndop, Cameroon and the implications for gender roles. J Int Women Studies 2007, 8:133-147.

32. Yengoh GT, Armah FA, Svensson MGE: Technology Adoption in Small-scale Agriculture. Dortmund, Germany: Science Technology \& Innovation Studies; 2010:5.

33. Davis K, Nkonya E, Kato E, Mekonnen DA, Odendo M, Miiro R, Nkuba $\mathrm{J}$ : Impact of Farmer Field Schools on Agricultural Productivity and Poverty in East Africa.: World Development:: IFPRI Discussion Paper 00992, The International Food Policy Research Institute (IFPRI). Washington DC: USA; 2011.

34. Brown ME, Hintermann B, Higgins N: Markets, climate change, and food security in West Africa. Environ Sci Technol 2009, 43:8016-8020.

35. MINEPAT: Autosuffisance et Sécurité Alimentaires au Cameroun: Une Analyse Basée Sur la Flambée des Prix des Produits Alimentaires de Première Nécessité Yaoundé: Comite de Pilotage du Developpement Rural, Ministere de L'economie de la Planification et de L'amenagement du Territoire; 2008.

36. Bationo A: Constraints and New Opportunities for Achieving a Green Revolution in Sub-Saharan Africa through Integrated Soil Fertility Management. California, USA: The Proceedings of the International Plant Nutrition Colloquium XVI, Department of Plant Sciences, UC Davis; 2009.

37. Gruhn P, Goletti F, Yudelman M, Institute IFPR: Integrated Nutrient Management, Soil Fertility, and Sustainable Agriculture: Current Issues and Future Challenges. The International Food Policy Research Institute (IFPRI), Washington DC: USA; 2000

38. Negin J, Remans R, Karuti S, Fanzo JC: Integrating a broader notion of food security and gender empowerment into the African Green Revolution. Food Security 2009, 1:351-360.

39. Denning G, Kabambe P, Sanchez P, Malik A, Flor R, Harawa R, Nkhoma P, Zamba C, Banda C, Magombo C: Input subsidies to improve smallholder maize productivity in Malawi: toward an African Green Revolution. PLOS Biol 2009, 7:e1000023.

40. Bumb BL, Johnson ME, Fuentes PA: Policy Options for Improving Regional Fertilizer Markets in West Africa. Washington DC: IFPRI Discussion Papers 01084; The International Food Policy Research Institute (IFPRI); 2011.

41. Folefack AJJ: Factors influencing the use of compost from household waste in the Centre Province of Cameroon. J Hum Ecol 2008, 24:77-83.

42. Folefack AJJ: The substitution of mineral fertilizer by compost from household waste in Cameroon: economic analysis with a partial equilibrium model. J Waste Manage Res 2008, 26:1-17.

43. Fofana B, Zida Z, Ezui G: Promoting Sustainable Crop-Livestock Integration Through Farmer's Participation and Integrated Soil Fertility Management in the Sahel of West Africa. In Soil Fertility Improvement and Integrated Nutrient Management - A Global Perspective. Edited by Whalen JK. Rijeka, Croatia: In Tech; 2012:273.

44. Vanlauwe B, Bationo A, Chianu J, Giller K, Merckx R, Mokwunye U, Ohiokpehai O, Pypers P, Tabo R, Shepherd K: Integrated soil fertility management. Operational definition and consequences for implementation and dissemination. Outlook Agric 2010, 39:17-24.

45. Oerke EC: Crop losses to pests. J Agric Sci 2006, 144:31-43.

46. West JS, Townsend JA, Stevens M, Fitt BDL: Comparative biology of different plant pathogens to estimate effects of climate change on crop diseases in Europe. Eur J Plant Pathol 2012, 33(1):315-331.

47. Garrett K, Dendy S, Frank E, Rouse M, Travers S: Climate change effects on plant disease: genomes to ecosystems. Annu Rev Phytopathol 2006, 44:489-509.

48. Mba C, Guimaraes EP, Ghosh K: Re-orienting crop improvement for the changing climatic conditions of the 21 st century. Agric Food Security 2012, 1:7.

49. Seufert V, Ramankutty N, Foley JA: Comparing the yields of organic and conventional agriculture. Nature 2012, 485:229-232.

50. Pretty J: Agricultural sustainability: concepts, principles and evidence. Philos Trans R Soc B Biol Sci 2008, 363:447-465.

51. FAOSTAT: Agriculture Organization of the United Nations Statistical Database Rome, Italy: Food and Agriculture Organization of the United Nations; http://www.faostat.fao.org; Accesses on 20 February 2012

52. FAO: The State of Food Insecurity in the World. Viale delle Terme di Caracalla. Rome: Food and Agriculture Organization of the United Nations; 2001.

53. Rosegrant MW, Cline SA: Global food security: challenges and policies. Science 2003, 302:1917-1919.

54. Sanchez PA: A smarter way to combat hunger. Nature 2009, 458:148. 
55. Boserup E: The Conditions of Agricultural Growth: The Economics of Agrarian Change Under Population Pressure. Chicago: Aldine; 1965.

56. Johnston BF, Mellor JW: The role of agriculture in economic development. Am Econ Rev 1961, 51:566-593.

57. Johnston BF, Kilby P: Agriculture and Structural Transformation: Economic Strategies in Late-developing Countries. New York: Oxford University Press; 1975.

58. MINADER: Document de Strategie de Developpement du Secteur Rural Actualisation 2005. 2nd edition. Yaoundé, Cameroun: Ministry of Agriculture and Rural Development; MINADER; 2005.

59. Quaye AK, Hall CAS, Luzadis VA: Agricultural land use efficiency and food crop production in Ghana. Environ Dev Sustain 2010, 12:967-983.

doi:10.1186/2048-7010-1-19

Cite this article as: Yengoh: Determinants of yield differences in smallscale food crop farming systems in Cameroon. Agriculture \& Food Security 2012 1:19.

\section{Submit your next manuscript to BioMed Central and take full advantage of:}

- Convenient online submission

- Thorough peer review

- No space constraints or color figure charges

- Immediate publication on acceptance

- Inclusion in PubMed, CAS, Scopus and Google Scholar

- Research which is freely available for redistribution 